Joanna Milewska-Kozłowska

Warszawa

\title{
Retrospektywna bibliografia narodowa Niemiec online (VD 16, VD 17, VD 18). Prezentacja baz
}

O tym jak wiele korzyści przynoszą internetowe bazy, katalogi czy repozytoria nie trzeba w dzisiejszych czasach nikogo przekonywać. Najważniejsze, by wiedzieć o ich istnieniu, umieć do nich dotrzec i efektywnie wykorzystać. Niniejszy przyczynek ma na celu omówienie trzech katalogów dostępnych w sieci (imponujących pod względem zawartości i metod pracy) powstałych w Niemczech na przestrzeni ostatnich 40 lat. Mowa o spisach znanych pod akronimem VD (Das Verzeichnis der im deutschen Sprachbereich erschienenen Drucke des 16, 17, 18 Jahrhunderts), rejestrujących piśmiennictwo $\mathrm{z}$ obszaru niemieckojęzycznego - Niemiec, Austrii, części Szwajcarii i Alzacji (niezależnie od języka tekstu), które tworzą niemiecką retrospektywną bibliografię narodową wieków XVI-XVIII*. Według zamysłu twórców VD, omawiana inicjatywa wypełnia, istniejąca do tej pory w niemieckiej bibliografii narodowej, lukę chronologiczną dla druków z okresu 1501-1800¹. Funkcji takiej bibliografii nie pełnią bowiem ani wydane w XIX w. katalogi Heinsiusa i Kaysera², będące retrospektywnymi spisami księgarskimi (z założenia bowiem, katalogi te są niekompletne a opisy druków prezentują w spo-

${ }^{*}$ Składam serdeczne podziękowanie dr Claudii Fabien z BSB München, za podarowanie materiałów nezbędnych do sporządzenia niniejszego przyczynku.

${ }^{1}$ Najwcześniejsze druki - inkunabuły - są rejestrowane w Gesamtkatalog der Wiegendrucke. Pierwszy tom katalogu ukazał sie w 1925 roku. Obecnie projekt kontynuuje Staatsbibliothek zu Berlin Preussischer Kulturbesitz w formie bazy internetowej.

${ }^{2}$ Ch. G. Kayser (Hrsg.), Vollständiges Bücher-Lexicon: enthaltend alle von... bis zu Ende des Jahres... gedruckten Bücher (1750-1864), Bd. 1-16, Leipzig 1834-1866; W. Heinsius, Allgemeines Bücher-Lexicon oder vollständiges alphabetisches Verzeichnis der von 1700. bis Ende 1892. erschienenen Bücher, welche in Deutschland und in den durch Sprache und Literatur damit verwandten Ländern gedruckt worden sind: 17001810, t. 1-2, Leipzig 1812. 
sób skrócony) ani późniejszy Gesamtverzeichnis des deutschsprachigen Schrifttums $(\mathrm{GV})^{3}$ wykazujący wybiórczo publikacje z XVIII w. tworzenie niemieckiej retrospektywnej bibliografii narodowej nastapiło właśnie poprzez budowę katalogów: VD 16-18, dostępnych nieodpłatnie w internecie. Ostatni z nich - baza VD 18, znajduje się w fazie testowania, zatem siłą rzeczy w niniejszym tekście poświęcono jej najmniej miejsca. Wszystkie trzy bazy powstały i w znacznym stopniu są nadal tworzone dzięki wsparciu finansowemu Niemieckiego Towarzystwa na Rzecz Wspierania Nauki (Deutsche Forschungsgemeinschaft - DFG).

\section{Trochę historii... VD 16}

Prace nad niemiecką retrospektywną bibliografią narodową rozpoczęto w 1969 roku w Herzog August Bibliothek w Wolfenbüttel (dalej HAB) przyjmując za podstawę szesnastowieczny zasób tej książnicy. Na początku spisano sygnatury druków z tego okresu, do których w następnej kolejności dodano nazwiska autorów i tytuły odnotowanych dzieł. Przy tworzeniu wykazów druków uwzględniono obszar językowy według kryteriów Josefa Benzinga zastosowany w Die Buchdrucker des 16. und 17. Jahrhunderts im deutschen Sprachgebiet i w spisie nakładców tegoż samego autora ${ }^{4}$ (takie kryteria przyjęto również później dla VD 17). Należy pamiętać, że w czasach sprzed ery komputerowej, tworzony spis miał postać tradycyjnej kartoteki kartkowej. Ważną cezura dla prac nad VD 16 była data zjednoczenia Niemiec. Wówczas do współtworzenia bibliografii włączyły się również biblioteki z byłej NRD (głównie Universitäts- und Forschungsbibliothek Erfurt/Gotha). Pokłosiem wieloletnich wysiłków bibliotekarzy HAB w Wolffenbüttel, Bayerische Staatsbibliothek (BSB) w Monachium jak i wspomnianych wyżej bibliotek z Erfurt/Gotha, był 25-tomowy katalog obejmujaccy 22 tomy zrębu głównego i 3 tomy indeksów, wydawany w latach 1983-20005. Biorąc pod uwagę intensywny rozwój

\footnotetext{
${ }^{3}$ Gesamtverzeichnis des deutschsprachigen Schrifttums (GV) 1700-1910, bearb. unter d. Leitung von Hilmar Schmuck u. Willi Gozny, Bibliogr. und redakt. Beratung Hans Popst und Reiner Schöller, München 1979-1987, 160 Bände, 1 Nachtragsband.

${ }^{4}$ J. Benzing, Buchdruckerlexikon des 16. und 17. Jahrhunderts, 1963; 2 Aufl. 1981; w 2007 r. ukazało się nowe wyd. oprac. przez Christopha Reske - Die Buchdrucker des 16. und 17. Jahrhunderts im deutschen Sprachgebiet: auf der Grundlage des gleichnamigen Werkes von Josef Benzing, Wiesbaden 2007.

${ }^{5}$ Verzeichnis der im deutschen Sprachbereich erschienenen Drucke des XVI. Jahrhunderts, Abt. I-III, Bd. 1-25, Stuttgart 1983-2000. Na temat rozwoju baz zob. również H. Schnelling, Die Verzeichnisse der im deutschen Sprachraum erschienenen Drucke des 16., 17. und 18 Jahrhunderts. Kontinuität und Innovation, [w:] Schmelze des barocken
} 
technologii komputerowych, już w latach dziewięćdziesiątych było wiadomo, że publikacje tradycyjne nie zaspakajają w pełni potrzeb współczesnych badaczy w szybkim wyszukiwaniu edycji. Ówczesne innowacje techniczne, pozwoliły na przeniesienie treści drukowanych tomów do baz komputerowych w systemie Aleph, w wyniku czego powstała wersja pośrednia VD 16 dostępna w sieci. Dzięki nowemu narzędziu stało się możliwe bieżące uzupełnianie bibliografii o nowe, dotąd nienotowane edycje. Już bowiem w trakcie wydawania kolejnych tomów okazało się, że nie zawiera wszystkich germaników, o czym świadczyły zgłoszenia z innych niemieckich (oraz zagranicznych) bibliotek. Materiał zebrany do suplementu, wprowadzono już tylko do wersji elektronicznej VD 16 a nowe rekordy otrzymały przed numerem symbol literowy ZV (Zusatzverzeichnis) i cytuje się je analogicznie jak te z wersji drukowanej (np. VD 16 ZV 23509). Krokiem następnym w rozwoju bazy było włączenie opisów egzemplarzy pomijanych dotąd dubletów oraz modyfikacja opisów: dodawanie tytułów ujednoliconych, tytułów dzieł współwydanych (acceditów). Z czasem zaczęto również dołączać do rekordów wersję zdigitalizowaną opisywanych druków. Docelowo każdy opis ma być zlinkowany z wersją cyfrową wybranego egzemplarza.

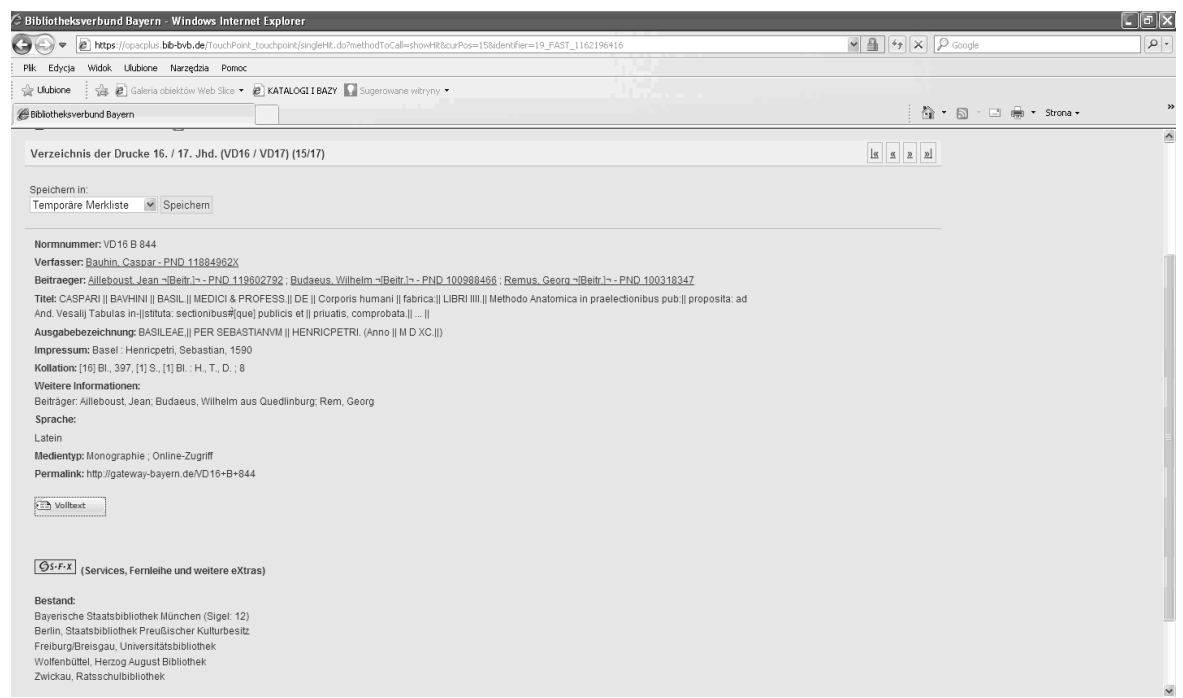

Il. 1. Rekord w bazie VD 16 z dostępem do wersji cyfrowej egzemlarza; opis przeniesiony z wersji drukowanej do bazy online, zachowuje swój pierwotny nr VD.

Eisbergs? Das VD 17 - Bilanz und Ausblick, „Bibliothek und Wissenschaft”, 43:2010, s. 199-211. 
Mówiąc o digitalizacji druków XVI wieku dostępnych w VD 16, należy wspomnieć o trzech projektach cyfrowego utwalania tego zasobu ${ }^{6}$. Pierwszy z nich rozpoczął się w 2006 r. digitalizacją edycji z 1. 1501-1517 ze zbiorów historycznych BSB w Monachium (procesowi temu poddano łącznie 4234 dzieła). Projekt ten formalnie został już zamknięty, chociaż nadal jest uzupełniany o skany dzieł znajdujących się w bibliotece w Halle (Universitäts- und Landesbibliothek Sachsen-Anhalt ULB), których nie posiada książnica bawarska. Kolejny etap prac przypadł na lata 2007-2009 - zdigitalizowano wówczas druki z 1. 1518-1600, które ze względu na stan zachowania kwalifikowały się do skanowania tzw. „maszynowego” (odbywa się bez udziału człowieka); akcja objęła 11932 egzemplarzy. Ostatni projekt, przewidziany na 1. 2011-2013, obejmuje tzw. ,trudne przypadki“ czyli książki, których nie można poddać masowej cyfryzacji. Chodzi tu m. in. o egzemplarze w złym stanie zachowania (np. ze słabą struktura papieru), czy też woluminy, które ze względu na swą objętość lub zbyt wąski margines wewnętrzny wymagają indywidualnego potraktowania i bardziej specjalistycznego sprzętu.

Baza VD 16 jest posadowiona na serwerze bawarskiej sieci bibliotecznej i dostępna przez Gateway Bayern ${ }^{7}$. Odnotowuje obecnie około 110000 tytułów w 385800 egzemplarzach, pochodzących z ponad 260 bibliotek. W tym zawiera ponad 26649 nowych, nienotowanych w wersji drukowanej tytułów, z tego 17591 z „kartkowego” suplementu (konwersji opisów dokonano w 1993 r.) $)^{8}$. Możliwe, że jest to dopiero połowa tego, co zostało opublikowane drukiem i mogłoby być zarejestrowane w VD $16^{9}$. Jak podkreśla Claudia Fabian, kierownik oddziału Książki Rzadkiej BSB w Monachium, jest to najobszerniejsza retrospek-

${ }^{6} \mathrm{Na}$ temat digitalizacji zbiorów BSB z XVI wieku zob. G. Janczewski, Masowa digitalizacja XVI-wiecznych dziel w Bawarskiej Bibliotece Państwowej, [w:] EBIB, 7:2009 (107), Digitalizacja w Polsce i Europie. Komunikat - http://www.nowyebib.info /2009/107/a.php?janczewski.

${ }^{7}$ C. Fabian, Die geplante Nationalbibliographie für das 18. Jahrhundert, VD 18, in Kontinuität zu VD 16 und VD 17, [w:] „Jahrbuch Kirchliches Buch- und Bibliothekswesen", 2007/08, s. 45.

${ }^{8}$ C. Fabian, Anreichung, Ausbau und internationale Vernetzung: Zur Fortfuhrung des Verzeichnisses der im deutschen Sprachbereich erschienenen Drucke des 16. Jahrhunderts (VD 16), „Zeitschrift für Bibliothekswesen und Bibliographie”, 57:2010, s. 321332, tu s. 322, dane X 2009 r.; na stronie www.vd17 czytamy już o 27000 rekordów z suplementu - dostęp cytowanych stron www - luty $2013 \mathrm{r}$.

9 J. Beyer, How complete are the German national bibliographies for the sixteenth and seventeenth centuries (VD16 and VD17)?, [w:]M. Walsby, G. Kemp (Hrsg.), The book triumphant. Print in transition in the sixteenth and seventeenth centuries (= Library of the written word, Bd. 15 = The handpress world, Bd. 9). Leiden/Boston 2011, s. 57-77, cyt. za http://de.wikipedia.org/wiki/VD_16. 
tywna bibliografia narodowa dla omawianego okresu. Dla porówniania, z analogicznego przedziału czasowego, ESTC (The English Short Title Catalogue) odnotowuje 15322 druków a STCN (Short Title Catalogue Netherlands) ok. $6000^{10}$.

Finansowa pomoc DFG dla bibliograficznego opracowywania druków do VD 16 została zakończona w 1999 roku $^{11}$, ale co warto zaznaczyć, baza jest nadal udoskonalana, a opiekę nad nią sprawuje od 2004 roku Bawarska Biblioteka Państwowa w Monachium. Tam też mieści się centrum koordynacyjne, w którym pracują 2 osoby (w tym jedna emerytowana wolontariuszka) czuwające nad merytoryczną jakością opisów. Jak wspomniano wyżej, nie jest to baza kompletna, nadal zgłaszane są druki nienotowane w VD 16, zarówno przez biblioteki niemieckie jak i przez zagraniczne książnice. Również w literaturze naukowej można znaleźć sygnały o drukach nienotowanych w VD $16^{12}$. Bazę uzupełnia się również dzięki nowym nabytkom BSB w Monachium, przeznaczonych dla „Zbioru Niemieckich Druków” (,Sammlung deutscher Drucke”) ${ }^{13}$.

\section{VD 17}

W odróżnieniu od VD 16, spis germaników z rejonu niemieckojęzycznego $\mathrm{z}$ lat 1601-1700, powstawał od samego początku w formie elektronicznej ${ }^{14}$. Wzorem dla VD 17 były katalogi fotograficzne Biblioteki Uniwersyteckiej we Wrocławiu i HAB w Wolfenbüttel - oparte na fotokopiach stron tytułowych, uzupełniane niezbędnymi danymi biblio-

${ }^{10}$ C. Fabian, Anreichung , Ausbau und internationale Vernetzung..., s. 321. Dane z STCN.

${ }^{11}$ DFG wznowiło finansowanie w 2006 roku, ale już tylko na digitalizację starych druków.

${ }^{12}$ Jak podaje C. Fabian, Anreichung ..., s. 321 - W. Kelly, Index of prints not listed in VD 16, „Guttenberg Jahrbuch”, 84:2009, s. 271-288 oraz tenże, Supplement to VD 16 - Index of Prints, „Guttenberg Jahrbuch”, 85:2010 - tam już niektóre wymienione druki posiadają $\mathrm{nr} Z \mathrm{~V}$.

${ }_{13}$ BSB to jedna z sześciu bibliotek niemieckich tworzących Sammlung Deutscher Drucke. Biblioteki te, w kooperacji odpowiedzialne są za gromadzenie drukowanego piśmiennictwa z niemieckiego obszaru kulturowego i językowego, od początku wynalezienia druku po czasy współczesne. Książnice starają się, by egzemplarz niemieckiej publikacji znalazł się w jednej z bibliotek w Niemczech. BSB jest odpowiedzialna za uzupełnianie, w miarę możliwości w sposób pełny, zbioru druków niemieckich z XVI w. Analogicznie - HAB odpowiada za kompletność publikacji z wieku XVII, Niedersächsische Staats- und Universitätsbibliothek Göttingen z wieku XVIII, UB Frankfurt am Main - druki z 1. 1801-1870, SBPK - z okresu 1871-1912, Deutsche Nationalbibliothek - od 1913 -.

${ }^{14} \mathrm{O}$ inicjatywie VD 17, omawiając stan z początku XXI w., nadmienia W. Król, Stare druki w sieci, [w:] Oblicza kultury ksiażki. Prace i studia z bibliologii i informacji naukowej, Wrocław 2005, s. 183. 
graficznymi ${ }^{15}$. Pierwsze rozmowy na temat możliwości stworzenia VD 17 miały miejsce już w sierpniu 1978 roku $^{16}$, jednak katalogowanie rozpoczęło się 1 lipca 1996 roku. Początkowo w projekcie uczestniczyły trzy biblioteki, z czasem zaczęły się przyłączać kolejne. W efekcie bazę współtworzyły: Staatsbibliothek zu Berlin - Preußischer Kulturbesitz, Sächsische Landesbibliothek / Staats- und Universitätsbibliothek Dresden, Niedersächsische Staats- und Universitätsbibliothek Göttingen, Universitäts- und Forschungsbibliothek Erfurt/Gotha, Universitäts- und Landesbibliothek Sachsen-Anhalt Halle, Herzogin Anna Amalia Bibliothek Weimar, HAB Wolfenbüttel, Stadtbibliothek Nürnberg. Na potrzeby tej bibliografii książnice tworzyły opisy starych druków na nowo, czyli katalogowały $\mathrm{z}$ autopsji lub też dodawały swoje sigla do opisów już istniejących (tak też było na późniejszym etapie tworzenia VD 16). W ten sposób obie bazy (VD 16 i VD 17) stały się nie tylko częścią planowanej retrospektywnej bibliografii, ale służą równocześnie rejestracji zasobu poszczególnych bibliotek. Dynamiczny rozwój VD, poza wieloma korzyściami, przyniósł także pewną negatywną konsekwencję, w postacji dublowania opisów. Wiele książnic opracowało część swojego zasobu dwukrotnie (często przy wsparciu środków tej samej instytucji - DFG), raz $\mathrm{w}$ ramach konwersji, powtórnie na potrzeby narodowej bibliografii ${ }^{17}$. Bywały zatem przypadki, że te same druki - czasem różnie skatalogowane, znajdowały się w dwóch osobnych bazach: w katalogu lokalnym danej biblioteki oraz w VD 17 (tzn. w internecie można było znaleźć dwa niejednakowe opisy dla tego samego egzemplarza). W celu ujednolicania opisów bibliograficznych, wszystkie dane z VD 17 przejęto do Gemeinsamer Bibliotheksverbund (GBV), co zrealizowano latem 2007 roku $^{18}$; tym samym pozbywając się zdublowanych opisów.

VD 17 zawiera nie tylko rekordy bibliograficzne. Z założenia do każdego opisu dołącza się skany tzw. stron kluczowych (Schlüsselseite, tj. kartę tytułowa, strony z dedykacja, początek tekstu głównego, kolofon - jeśli taki występuje i ewentualnie sygnety drukarskie), które ułatwiają identyfikację starego druku. Podaje się też sygnaturę egzemplarza, z którego wykonano wersję cyfrową. $\mathrm{W}$ momencie rozpoczęcia projektu nie

${ }^{15}$ T. Bürger, Die Vermessung der Bücherwelt, Eine Erfolgsgeschichte der Deutschen Forschungsgemeinschaft, [w:] Bibliotheken in Sachsen, s. 161.

${ }^{16}$ Dokładne kalendarium powstawania bazy VD 17 zob. C. Bubenik, Projektdaten zum VD 17 - ein Überblick, [w:] Bibliothek und Wissenschaft..., s. 27-32. Na temat również C. Fabian, Das VD17 - ein wunderbares Geschenk..., s. 17 i n. s. 49.

${ }^{17}$ C. Fabian, Die geplante Nationalbibliographie für das 18. Jahrhundert, VD 18...,

${ }^{18}$ C. Fabian, T. Stäcker, A. Wehmeyer, dz. cyt., s. 196. 
było jeszcze możliwości technicznych, by dodawać do opisów zeskanowane dzieła w całości. Sytuacja zmieniła się w 2007 roku, kiedy zaczęto realizować projekt, ponownie wspierany przez środki DFG, Digitalisierung der in nationalen Verzeichnissen nachgewiesenen Drucke - VD 16/ $V D$ 17. Według danych z końca 2008 roku w VD 17 znajdowało się 6800 zdigitalizowanych dzieł ${ }^{19}$, w 2011 już ponad 29000 a w grudniu 2012 - 68000 tytułów w całości zeskanowanych książek ${ }^{20}$.

W sumie baza obejmuje opisy ponad 282500 wydań w około $696000^{21}$ egzemplarzy i podobnie jak w przypadku VD 16 przypuszcza się, że dane te w $50 \%$ odzwierciedlają ówczesną produkcję wydawniczą ${ }^{22}$. Jak stwierdza Wolfgang Müller, ponad 150000 tytułów jest odnotowanych tylko w jednym egzemplarzu - to edycje unikatowe. Według tego badacza, rzadkość druków opisanych w VD 17 jest raczej regułą niż wyjątkiem. Zaznacza jednak, że w samych Niemczech jest jeszcze wiele bibliotek, które nie współpracowały do tej pory z VD. Ich zbiory również moga kryć nieznane edycje ${ }^{23}$. Nie negując faktu notowania w bazie wydań unikatowych, należy jedynie stwierdzić, iż na ostateczną ocenę ich ilości w obrębie siedemnastowiecznych germaników musimy jeszcze poczekać. VD 17 jest wciąż rozbudowywana - jej administracja i nadzór merytoryczny leży w gestii trzech bibliotek: BSB Monachium, HAB Wolfenbüttel i Staatsbibliothek zu Berlin, nazywanych w języku niemieckim „Trägerbibliothek”. Co dwa lata zmienia się przewodnictwo tego gremium. Od marca 2011 roku należy ono do Staatsbibliothek zu Berlin, a osobą koordynującą przedsięwzięcie jest kierownik działu „Historische Drucke“. Natomiast pod względem technicznym czuwa nad nią centrala GBV w Getyndze ${ }^{24}$. Ponadto dodatkowym walorem baz VD 16 i 17 jest

${ }^{19}$ W. Müller, Das VD 17 in Zahlen: statistische Aussagen - neue Erkenntnisse? [w:] Bibliothek und Wissenschaft..., s. 49

${ }^{20}$ Zob. http://www.vd17.de/index.php?article_id=25\&clang=0 - do 2020 planuje się udostępnić 90\% zawartych w VD tytułów; dane dot. 2011 r. ze strony www (wersja do maja 2013).

${ }^{21}$ Tamże; por. dane statystyczne bazy - W. Müller, dz. cyt., s. 43 (biorąc pod uwagę dzieła wielotomowe - 270400 opisów bibliorgraficznych, co daję 650000 egzemplarzy). Por. C. Fabian, Die geplante Nationalbibliographie..., s. 52 - podaje liczbę 567000 egz.

${ }_{22} \mathrm{~J}$. Beyer, How complete are the German national bibliographies for the sixteenth and seventeenth centuries (VD 16 and VD 17)?, dz. cyt., s. 57-77, cyt. za http://de.wikipedia.org/wiki/VD_17

${ }^{23}$ W. Müller, dz. cyt., s. 46-47 - brakuje bibliotek z południowego-zachodu Niemiec, np. Hesji, Nadrenii oraz ,wysokiej” północy, czyli regionu z ważnymi miejscami druku i bibliotekami. Brak poza tym książnic austriackich, szwajcarskich, krajów Beneluksu i byłego niemieckiego wschodu (pod względem wyznaniowym - ,górują" biblioteki z piśmiennictwem protestantckim - wyjątek stanowi BSB). s. 45 .

${ }^{24}$ C. Fabian, Die geplante Nationalbibliographie für das 18. Jahrhundert, VD18..., 
możliwość jednoczesnego przeszukiwania ich zawartości. To bardzo wygodne rozwiązanie, gdyż wiele pierwodruków szesnastowiecznych było wznawianych w kolejnych wiekach. Zatem za pośrednictwem jednego interfejsu stało się możliwe przeszukiwanie dzieł wydanych w dwóch stuleciach.

\section{VD 18}

Najmłodszą z omawianych inicjatyw i jednocześnie prezentującą największy materiał badawczy jest baza, obejmująca germanika z wieku $\mathrm{XVIII}^{25}$. Na etapie projektowania dyskutowano nad jej zasięgiem chronologicznym. Rok 1800 jest datą umowna, w wielu krajach przyjętą za koniec epoki książki tłoczonej ręcznie (do nich należy m. in. Polska). W Niemczech zaś za stare druki uważa się dzieła wydane do roku 1850, choć mówi się również o dacie 1830 jako tej, która oddziela okres manufaktury od początku masowej produkcji książki. Na potrzeby VD 18 przyjęto, głównie mając na uwadze obfitość materiału, że baza obejmować będzie tylko druki do 1800 roku włącznie ${ }^{26}$.

Prace nad projektem rozpoczęły się 1 listopada 2009 roku. Obecnie trwa jego faza wstępna, która ma na celu $\mathrm{m}$. in. wypracować metodę współpracy na kolejne lata ${ }^{27}$. W inicjatywie bierze udział pięć tzw. bibliotek pilotażowych: ULB Halle, SUB Göttingen, SLUB Drezno, SBPK Berlin, BSB Monachium. W przyszłości zostaną podjęte również decyzje co do tego, jakie jeszcze książnice będą współtworzyć bazę. Te, które tworzą VD 18 już dziś, pracują w różnych systemach i należą do różnych sieci bibliotecznych - Gemeinsame Bibliotheksverbund (GBV), Bibliotheksverbund Bayern (BVB), Südwestdeutscher Bibliotheksverbund (SWB). Ów fakt generuje pewne trudności techniczne i organizacyjne, co jest nieuniknione, biorąc pod uwagę skalę i rozmach całego przedsięwzięcia. W trwającej dwa lata fazie pilotażowej projektu założono, iż opracowanych zostanie 75000 druków (co równa się 18 mln zeskanowanych stron), a w kolejnym etapie, przewidzianym na sześć lat, planuje się

\footnotetext{
${ }^{25} \mathrm{Na}$ ten temat $-\mathrm{H}$. Schnelling, dz. cyt., s. 203 (trudności w szacunkach, bo brak w niemieckich bibliotekach $1 / 3$ niemieckiej produkcji); szczegółowo na temat przedsięwzięcia zob. T. Burger, C. Fabian, R. Schaab, B. Schneider-Kempf, H. Schnelling, M. Thaller, Das VD 18: eine Einladung ins 18. Jahrhundert, „Bibliothek: Forschung und Praxis", 32:2008, s. 195-202.

${ }^{26}$ Jak podaje R. Siegert, VD 18 - zum Diskussionsstand aus fachwissenschaftlicher Sicht, „Bibliothek: Forschung und Praxis”, 32:2008, nr 2, s. 203-208, tu s. 205: „Rok 1800 jest datą czysto mechaniczną i nie jest żadną cezurą bibliografia powinna kończyć się najwcześniej na 1832 roku, lepiej na 1850 ".

${ }^{27}$ T. Burger, C. Fabian, R. Schaab, B. Schneider-Kempf, H. Schnelling, M. Thaller, dz. cyt., s. 198n.; H. Schnelling, dz. cyt., s. 210-211.
} 
opracować 600000 tytułów, choć trudno dokładnie szacować docelową wielkość bazy. W tym miejscu warto zacytować Marka Twaina, którego słowa przypomniał Heiner Schnelling „Prognozy są trudną sprawą. Przede wszystkim, jeśli dotyczą przyszłości”28. Po zakończeniu projektu zostanie udostępniona pełna wirtualna biblioteka narodowa XVIII w.

VD 16 i 17, jak już wspomniano, to bazy, do których sporządzano lub też tworzy się nadal nowe rekordy bibliograficzne. Inaczej ma się sprawa z VD 18 - tu znajdować się będą opisy, które już istnieją w lokalnych systemach bibliotecznych. Zostaną one skorygowane i uzupełnione skanami obiektów. Wybór istniejących opisów ma się odbywać w znacznej części automatycznie - przez system komputerowy, co powoduje rozliczne trudności. Po pierwsze mamy do czynienia $\mathrm{z}$ drukami $\mathrm{w}$ różnych językach, zarówno w niemieckim jak i łacińskim, francuskim, greckim itd. - nie można zatem zastosować wyszukiwania przez kod języka. Również wyszukiwanie poprzez kod kraju jest sprawą skomplikowaną z powodu zmiany historycznych granic Niemiec (ze względu na ograniczenia czasowe projektu nie bierze się pod uwagę byłego niemieckiego wschodu), ale przewiduje się biblioteczną współpracę międzynarodową. W praktyce wygląda to następująco - stworzono ,pustą" bazę roboczą, do której biblioteki pilotażowe przesyłają opisy druków z przedziału czasowego 1701-1800. Następnie dokonuje się selekcji. Tytuły nie spełniające wymogów są usuwane z bazy, a te, które w niej zostają, otrzymują kolejny nr VD 18 (VD18-relevant), widoczny w poszczególnych systemach lokalnych oraz w KVK ${ }^{29}$. Obecnie w bazie znajduje się ponad 107 tys. tytułów druków osiemnastowiecznych ${ }^{30}$.

W Kolonii znajduje się centrala koordynująca całe przedsięwzięcie. Baza posadowiona została na serwerze jednego z instytutów miejscowego uniwersytetu (Institut für Historisch-Kulturwissenschaftliche Informationsverarbeitung der Universität zu Köln - Lehrstuhl); opiekuje się nią prof. Manfred Thaller.

\section{Zawartość baz i możliwości wyszukiwawcze}

Bazy VD 16-18 zawierają obszerny i różnorodny materiał badawczy. Nasuwa się więc pytanie, niezwykle istotne z punktu widzenia użytkownika, jaką informację uzyskujemy przeszukując owe katalogi i czy dotar-

${ }^{28}$ H. Schnelling, dz. cyt., s. 211.

29 C. Fabian, Die geplante Nationalbibliographie das 18. Jahrhundert, VD 18..., s. 47, 50. Na ten temat również. T. Burger, C. Fabian, R. Schaab, B. Schneider-Kempf, H. Schnelling, M. Thaller, dz. cyt.

${ }^{30}$ Zob. http://vd18-proto.bibliothek.uni-halle.de/ 
cie do niej jest szybkie i łatwe? By móc udzielić na nie odpowiedzi, należy zacząć od szczegółowego omówienia zawartości katalogów. Na stronie głównej portalu VD 18 znajdujemy informację, że Das Verzeichnis der im deutschen Sprachraum erschienenen Drucke des 18. Jahrhunderts (VD 18) jest retrospektywną bibliografią narodową $\mathrm{d} \mathrm{z} \mathrm{i} \mathrm{e} 1 \mathrm{~d} \mathrm{r} \mathrm{u} \mathrm{k} \mathrm{o-}$ w a n y c h [podkreślenie JMK] z 1. 1701-1800 i nawiąuje do tradycji poprzednich projektów VD 16 i VD $17^{31}$. Określenie „Druckwerke” czyli dzieła drukowane, jest pojęciem bardzo ogólnym, wymagającym doprecyzowania, bo jak pokaże analiza, zawartość poszczególnych baz nieco się różni. I tak, w swych założeniach VD 16 obejmuje wszystkie znane druki, które wydano w historycznym niemieckim obszarze językowym z lat 1501-1600, nie zawiera jednak druków jednokartkowych, map i nut. Jeśli chodzi o VD 17, mają się tu znajdować wszystkie niemieckojęzyczne tytuły oraz dzieła niezależnie od języka w jakim zostały spisane, wydane na obszarze ,szeroko pojętych” Niemiec, poza nutami i mapami. Odnotowuje jednak druki jednokartkowe i czasopisma, przy czym każdy tom wydawnictwa ciagłego otrzymuje osobny rekord ${ }^{32}$. Natomiast w VD 18 nie uwzględnia się map, atlasów, nut, grafiki, plakatów, druków przetłumaczonych z niemieckiego na języki obce, nawet jeśli dotyczą Niemiec, czasopism oraz wydań faksymilowych i mikroform.

Każdy druk w prezentowanych bazach opisany jest w rekordzie bibliograficznym, który sporządza się według reguł obowiązujących w katalogowaniu starych druków w naukowych bibliotekach niemieckich - RAKWB Alte Drucke ${ }^{33}$. Mimo podyktowanych schematem elementów wspólnych, opisy te różnią się pod względem zawartych w nich informacji. Jest to związane zarówno z tym, że powstały w różnym czasie (i były dziełem różnych osób), jak i z racji wymogów wynikających z finansowania prac nad katolagami, a więc często $\mathrm{z}$ ograniczenia czasowego. $\mathrm{W}$ opisach VD 16 bardzo dokładnie odpisuje się kartę tytułową. Wynika to z tradycji wiernego jej odwzorowywania, tak jak to miało miejsce w katalogu drukowanym. Transliterowano tytuł i adres wydawniczy, uwzględniając podział na wiersze oraz pisownię wielkich i małych liter. Inaczej sprawa wyglądała przy tworzeniu bazy VD 17, gdzie już nie troszczono się

\footnotetext{
${ }^{31}$ Zob. www.vd18.de

${ }^{32}$ Co jest odmienną praktyką niż w przyjętych zasadach katalogowania w polskim Narodowym Uniwersalnym Katalogu Centralnym NUKAT; por. H. Mieczkowska, $\mathrm{Ka}$ talogowanie starych druków w Narodowym Uniwersalnym Katalogu Centralnym (NU$K A T)$, , Roczniki Biblioteczne”, 53:2009, s. 205-221.

${ }_{33}$ Regeln für die Katalogisierung alter Drucke, erarb. von der Arbeitsgruppe des Deutschen Bibliotheksinstituts „RAK-WB und Alte Drucke”, Hrsg. und eingeleitet von Klaus Haller, Berlin 1994.
} 
o dokładny odpis tytułu, gdyż od samego początku istniała możliwość dołączania materiału ilustracyjnego - najpierw wspomnianych wcześniej stron kluczowych, a od niedawna całych zdigitalizowanych dzieł. Również przy rekordach w VD 18 zamieszcza się skany całego druku, choć w tym przypadku postanowiono wrócić do dokładnego odpisu karty tytułowej, tzn. odzwierciedlania małych i wielkich liter, ich różnorodnego użycia, np. uwzględnienia oboczności u/v.

Ważnym elementem opisu, jeśli chodzi o identyfikację wydań starych druków jest fingerprint. Składa się na niego: data wydania, sekwencja 16 znaków, wytypowanych w ściśle ustalony sposób z określonych stron druku, kod informujący o formie zapisu daty oraz siglum biblioteki, z której druk pochodzi. Fingerprint jest dodawany konsekwentnie w VD 17, a pomijany w VD 18 (choć zgodnie z założeniami miał być uwzględniany w rekordach druków wydanych do $1730 \mathrm{roku}^{34}$ ) jak i VD 16 . W tym ostatnim przypadku, wynika to ponownie z tradycji katalogu drukowanego, w którym brak takiej informacji. Uzupełnianie fingerprintu w wielu tysiącach opisów byłoby zbyt czasochłonne. W konsekwencji VD 17 odnotowuje więcej wydań wariantowych niż VD 16, bowiem fingerprint jest często elementem roztrzygającym czy mamy do czynienia $z$ identyczną edycją, czy odmiennym odbiciem. Można jedynie przypuszczać, że gdyby przy opracowywaniu druków szesnastowiecznych uwzględniano fingerprint, w katalogu znalazłoby się znacznie więcej pozycji, niż to ma miejsce w chwili obecnej.

$\mathrm{Z}$ informacją o wydaniach wariantowych mamy zatem do czynienia w bazie VD 17 i suplemencie do bazy VD 16. Jako identyczne, traktuje się te dzieła, które posiadają taki sam fingerprint i strony kluczowe. Jeśli te elemety (nawet w najmniejszym stopniu) są różne, każdy druk traktuje się jako oddzielne wydanie i opisany zostaje w osobnym rekordzie bibliograficznym. Natomiast w przypadku, gdy różnice dotyczą pozostałej części składu - wówczas otrzymują jeden opis bibliograficzny i w uwagach (Anmerkungen) podaje się, na czym one polegają. Tak więc, jeśli na verso karty tytułowej w jednym egzemplarzu znajduje się ilustracja, a na drugim jej nie ma - wówczas obydwa woluminy opisane są w jednym rekordzie bibliograficznym, w którym odontowuje się te różnice ${ }^{35}$. Biblioteki dodając swoje siglum do opisu, przy sygnaturze egzemplarza zaznaczaja,

${ }^{34}$ C. Fabian, Die geplante Nationalbibliographie für das 18. Jahrhundert, VD 18..., s. 52 .

${ }^{35} \mathrm{~W}$ polskim katalogu NUKAT każdy wariant starego druku otrzymuje osobny rekord. 
który wariant posiadają w swych zbiorach ${ }^{36}$. Jeśli rozbieżność polega na tym, iż w jednym druku występuje przedmowa, a w innym nie, w polu uwag podaje się tzw. Fingerprint alternatywny (Alternativer Fingerprint) ${ }^{37}$. W tym samym polu odnajdziemy również adres wydawniczy w formie występującej na druku. Reasumując - w zależności od tego, czego różnice dotycza, wydanie wariantowe czasem otrzymuje osobny rekord (z adnotacją: „nicht identisch als"), a niekiedy w polu uwag jednego rekordu opisuje się kilka wariantów. Informację o takich odbiciach można wyszukać w bazach poprzez słowo z opisu. Na chwilę obecną (wrzesień 2013 r.) w VD17 odnajdujemy 519 rekordów z uwaga „Variante”.

Przeszukiwanie zasobów internetowych przez słowo z opisu jest znane, wygodne i chętnie stosowane, np za pośrednictwem wyszukiwarki Google. Wiadomo jednak, iż nie jest to metoda w pełni efektywna. Korzystając z jakiegokolwiek katalogu bibliotecznego online, wystarczy, że wpiszemy formę nazwiska autora interesującego nas druku w innej postaci, niż ta, która została przyjęta do opisu bibliograficznego, i do pozycji już nie dotrzemy. By temu zapobiec, przy sporządzaniu opisów bibliograficznych, nie tylko starych druków, tworzy się hasła wzorcowe (KHW) dla autorów, instytucji sprawczych, ciał korporatywnych itd., a dla identyfikacji książki dawnej również dla ilustratorów, nakładców czy drukarzy. W takim haśle obok przyjętej formy podstawowej nazwiska czy instytucji sprawczej, podaje się tzw. hasła odrzucone, czyli różne oboczności tej nazwy. Dzięki temu, szukając również przez tego rodzaju terminy odnajdziemy w bazie poszukiwany przez nas druk. Sporządzanie rekordów do kartoteki haseł wzorcowych jest często bardzo czasochłonne, co sprawia, że na użytek katalogów VD nie sporząadza ich się wiele. W przypadku VD 16 stworzono noty dla wszystkich nazwisk tam wystepujących (to głównie nowe hasła), które w 2007 przekazano do ponadregionalnej kartoteki PND ( $\mathrm{w}$ j. niem. PND - Personennormendatei to odpowiednik polskiego KHW). Zrezygnowano $\mathrm{z}$ haseł wzorcowych dla drukarzy, adresatów dedykacji, a ich nazwiska podawane są w opisie w formie ujednoliconej. W VD 17 brak KHW dla adresatów dedykacji, czy osób współodpowiedzialnych za powstanie dzieła, takich jak np. autor przedmowy, autor wiersza na herb, cenzor, ilustrator. Nazwiska te podaje się tylko w formie występującej na druku (nach Vorlage angesetzt), co czasem skutkuje fałszywym namnożeniem tej samej osoby lub scaleniem kilku w jedną. Ale sporządza się omawiane hasła dla autora,

${ }^{36}$ Zob. np. VD 17 39:133446A, VD 17 3:309837.

${ }^{37} \mathrm{Na}$ temat definicji wydania/wariantu, zob. materiały na stronie www.vd17.de: Neuaufnahmen von VD-17-Titeln oraz VD-17-Arbeitsanweisungen. 
thumacza, wydawcy i typografa. Natomiast w VD 18 nie planuje się haseł wzorcowych dla adresatów dedykacji, cenzorów, ilustratorów (i prawdopodobnie dla innych osób współodpowiedzialnych), jak i dla drukarń. Jak zaznacza Claudia Fabian, hasła korporatywne (Körperschaften) nie odgrywaja w obu bibliografiach narodowych (VD 16 i 17) zasadniczej roli i dodaje się je bez powiązań z kartoteką haseł wzorcowych. Ważne, iż poprzez ustandaryzowaną formę wszystkie nazwiska drukarzy oraz nazwy miejscowości obecne w VD 16 są wyszukiwane w Tesaurusie CERL, dostępnym w sieci. ${ }^{38}$

W poszukiwaniu materiału badawczego, dużą pomocą są hasła rzeczowe, wprowadzane do rekordów bibliograficznych. Jednak tematowanie starych druków jest niezmiernie trudnym i czasochłonnym zadaniem. Jeśli chodzi o VD 16, to takie hasła wystepują w niewielkiej ilości opisów. Ich dodawania podjęto się podczas projektu digitalizacji druków z BSB z 1. 1501-1517 $7^{39}$. W VD 17 również brak dogłębnego opracowania rzeczowego (Sacherschliessung), które nie było możliwe w ramach tego przedsięwzięcia, z powodów czasowych i finansowych. W zamian baza oferuje możliwość wyszukiwania poprzez ok. 180 terminów, na które składają się zarówno gatunki literackie jak i formy literacko-wydawnicze (Gattungsbegriffen i Fachgruppenbezeichnungen). Ich nadawanie nie było jednak obowiązkiem dla opracowującego. Zatem nie wszystkie druki opisane w VD 17 mają dodaną kategorię Gattung/Fach ${ }^{40}$. W sumie sklasyfikowanych zostało 313524 tytułów, z czego ponad 70\% przypada na 11 terminów (m. in. dysertacje, druki okolicznościowe, kazania pogrzebowe, piśmiennictwo akademickie $)^{41}$. Te kategorie odnajdujemy również w VD 18, gdzie poza standardowymi możliwościami wyszukiwawczymi, jak autor, tytuł, czy słowo z opisu oraz Gattung/Fach, dostępne jest również przeszukiwanie dołączonych skanów pod kątem ich zawartości. Struktura wyszukiwawcza jest tak zbudowana, że pozwala na bezpośrednie dotarcie zarówno do oprawy jak i poszczególnych części druku. To wygodne „narzędzie”, szczególnie w książkach o znacznej objetości, umożliwia szybkie przejście do kolejnych passusów dzieła.

${ }^{38}$ CERL - Konsorcjum Europejskich Bibliotek Naukowych. C. Fabian, Die geplante Nationalbibliographie für das 18. Jahrhundert, VD 18..., s. 52-53.

${ }^{39}$ Tamże, s. 52.

${ }^{40}$ Pełny spis Gatungsbegriffen oraz inne możliwości wyszukiwawcze są dostępne na stronie www.VD17.de. Na temat ilości nadawanych tematów w VD 17, zob. zestawienie w W. Müller, dz. cyt., s. 53.

41 Dane procentowe (stan z października 2009) oraz omówienie terminów zob. D. Sommer, Gattungsbegriffe als Beispiel sachlicher Erschliessung im VD 17, [w:] Bibliothek und Wissenschaft..., s. 63. 


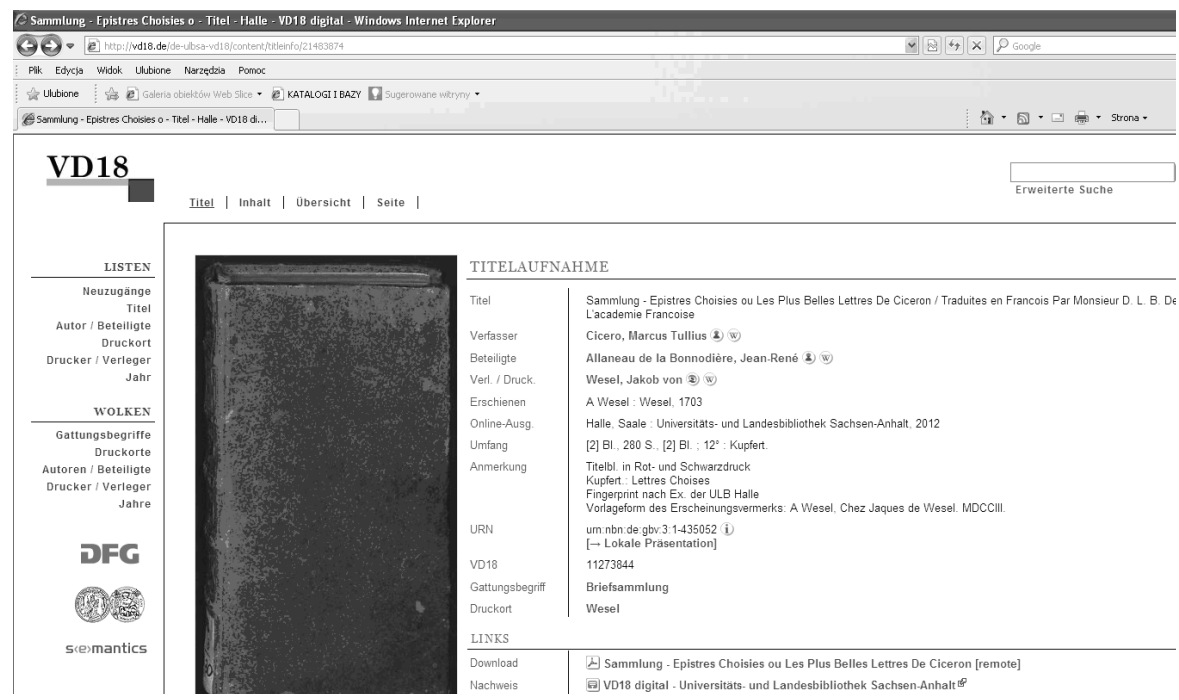

Il. 2. Opis bibliograficzny w VD 18 zbioru listów Cycerona wyd. w 1703 r.

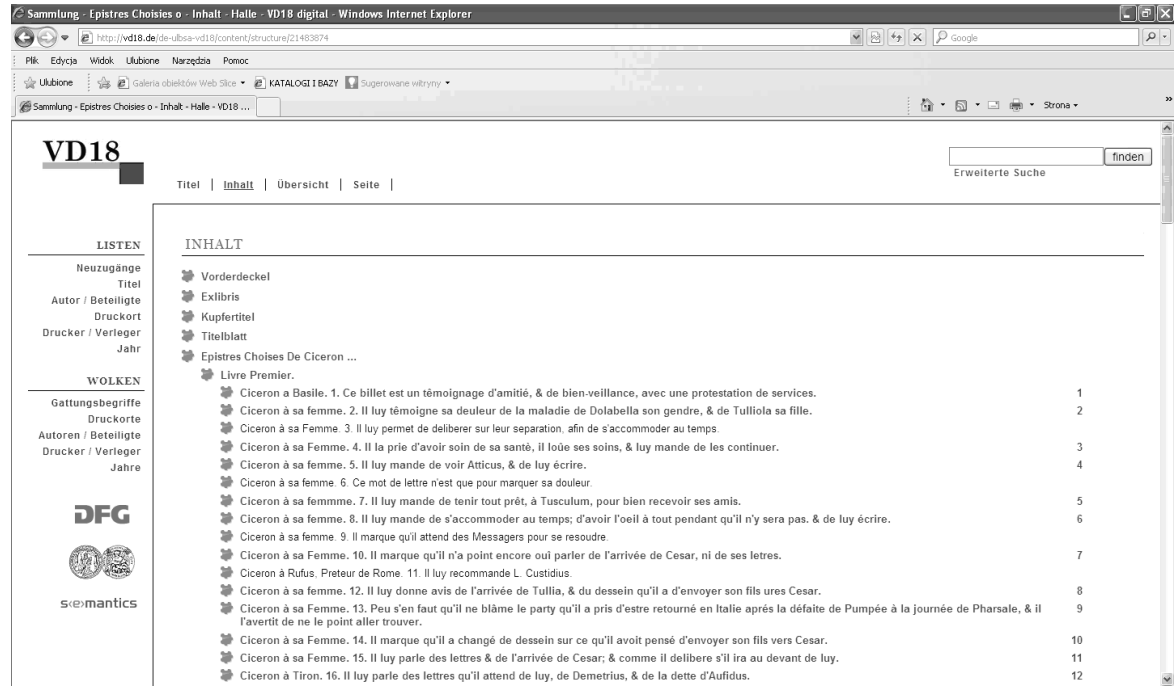

Il. 3. Schemat zawartości zdigitalizowanego druku (niem. Inhalt). Dzieło obejmuje 280 stron, na ekranie widoczna zawartość do s.12.

Osobną kwestią jest wyszukiwanie w bazach nazw właścicieli i znaków proweniencyjnych starych druków. Podstawowym celem VD16-18 jest stworzenie retrospektywnej bibliografii narodowej, nasuwa się więc pytanie, czy należy w niej umieszczać informacje o cechach indywidual- 
nych prezentowanych egzemplarzy ${ }^{42}$, a więc odnotowywać: rękopiśmienne notatki, pieczęcie, ekslibrisy poprzednich posesorów ksiag, oprawę, ale też, ujmując sprawę szerzej, takie informacje jak kolejność oprawienia poszczególnych części książki czy stopień ich kompletności. Wydawałoby się, że odpowiedź nasuwa się jedna - to nie miejsce na tego typu informacje. Zdania jednak na ten temat mogą być podzielone. Wiele osób uważa, iż odnotowywanie cech indywidualnych książek w katalogach, bazach jest niezbędne, gdyż stanowi cenny materiał dla badaczy różnych specjalności. Poza tym, umieszczanie tego typu uwag okazuje się być bezcenna w przypadku katastrof, takich jak kradzieże czy pożary. Jako egzemplifikacja posłużyć może historia Herzogin Anna Amalia Bibliothek w Weimerze. We wrześniu 2004 roku spłonęła część jej historycznych zbiorów i opisy woluminów tej książnicy (wraz ze skanami tzw. stron kluczowych ${ }^{43}$ ) znajdujące się w VD 17, w niektórych przypadkach stanowią na chwilę obecna, jedyny dostęp do edycji ${ }^{44}$. Powrócmy jednak do zapisów proweniencyjnych w omawianych katalogach. Podawanie znaków własnościowych w VD 17 pozostawiono do decyzji opracowującego i można zaobserwować, że coraz więcej bibliotek współtworzących tę bazę, uwzględnia je, umieszczając przy sygnaturze druku. W przypadku VD 16 proweniencje odnotowuje się tylko wówczas, jeśli książka pochodzi ze zrębu podstawowego (Gründungsbestand) a w przypadku VD 18 nie planuje się podawania takich informacji. Wyszukiwanie nazwisk kolekcjonerów, autorów odręcznych dedykacji lub też innych elementów opisu proweniencyjnego jest możliwe jedynie przez słowa zawarte w rekordzie (w VD17 również przez kategorię Provenienz), gdyż nie są to hasła kontrolowane przez kartotekę haseł wzorcowych. Stworzenie haseł ujednoliconych dla tego typu materiału wymagałoby zbyt dużego nakładu pracy bibliotekarzy, a co za tym idzie, dodatkowego wsparcia finansowego. Mając na uwadze potrzeby użytkownika idealnym rozwiązaniem byłaby osobna baza poświęcona znakom proweniencyjnym połączona $\mathrm{z}$ odpowiednimi opisami bibliograficznymi w katalogach lokalnych. O tego typu rozwiązaniu myśli się na gruncie polskich bibliotek naukowych ${ }^{45}$.

${ }^{42}$ Takie pytanie odnośnie VD 17 postawił Johannes Mangei, Exemplarspezifische Erschliessung im VD 17, [w:] Bibliothek und Wissenschaft..., s. 161-165, tu s. 161.

${ }^{43}$ J. Mangei, Exemplar..., s. 162, do specyfikacji Autor zalicza również miejsce przechowywania egzemplarzy jak i skany stron kluczowych n a których czasem znajdują się również znaki właśnościowe.

44 Tamże, s. 165.

${ }^{45}$ Postulat powstania takiej bazy został wysunięty podczas warsztatów dla katalogujących stare druki, które odbyły się Bibliotece Uniwersyteckiej w Poznaniu, 14-15 września 2010 r.; obecnie rozważa się zbudowanie ogólnopolskiej bazy proweniencji starych druków w ramach platformy SYNAT, por. „Z Badań nad Książką i Księgozbiorami Historycznymi”, 6:2012, s. 219-242. 


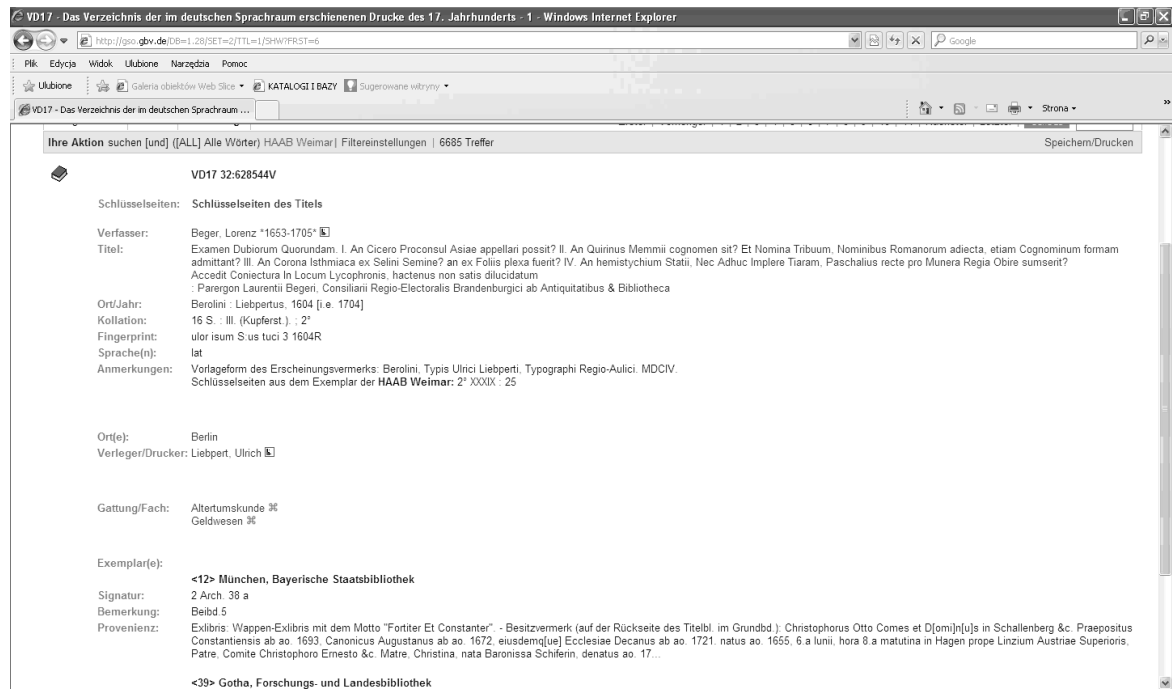

Il. 4. Opis bibliograficzny w VD 17, w którym podano proweniencję egzemplarza.

Równie ważna dla badaczy wielu specjalności jest możliwość wyszukiwania w katalogach bibliotecznych materiału graficznego. W prezentowanych bazach, na co zwracano już uwagę wcześniej, do rekordów dołacząne są skany stron kluczowych lub całej książki. Dzięki temu biblioteki posiadające egzemplarz zdefektowany lub wariantowy, mają możliwość odpowiednio go zidentyfikować porównując $\mathrm{m}$. in. materiał typograficzny: listwy, ozdobniki, czy sygnet drukarski. Jednak nie wszystkie informacje o tych elementach odnajdujemy w opisie bibliograficznym. W polu przewidzianym na opis objętości, uwzględnia się ilustracje, dołączane tablice, mapy czy frontispisy lecz nie są to informacje wyczerpujące. W VD 17 odnotowuje się liczbę rycin zajmujących całe strony w książce, a w przypadku występowania ilustracji o mniejszych rozmiarach podaje się jedynie wzmiankę ,il.” (niem. „Ill.”). Można w tym miejscu wyrazić życzenie, aby materiał ilustracyjny był opisywany bardziej szczegółowo, np. dokładniej wyliczał materiał graficzny, bez względu na jego rozmiary czy też w polu uwag zawierał notę o tematyce. Gdy wprowadzimy do wyszukiwarki skrót „Ill.”, otrzymamy 23073 opisy uwzględniające technikę, w jakiej ryciny wykonano - drzeworyt lub miedzioryt. ${ }^{46}$ Naj-

${ }^{46}$ D. Paisey, Aspekte zur Digitalisierung und Erschliersung der Druckgraphik anhand des VD 17 [w:] Bibliothek und Wissenschaft..., s. 167-171, tu s. 168., s. 168 - prawie 22000 trafień (stan na r. 2009). 
trudniej materiał graficzny wyszukuje się w VD 16. Co prawda w opisie bibliograficznym podaje się informacje o: ozdobnych ramkach, listwach, drzeworytach, miedziorytach, jednak z wykorzystaniem odpowiednich skrótów w polu przeznaczonym na dodatkowe informacje (Zusatzinformationen), tak jak to miało miejsce w katalogu drukowanym (np. $\mathrm{H}-$ oznacza nieliczbowane drzeworyty w tekście, D - sygnet drukarski, RLramki/listwy typograficzne wewnątrz druku $)^{47}$. Brakuje jednak możliwości przeszukiwania bazy przez nadmienione skróty. W VD 18 jest to już możliwe, choć jedynie poprzez słowo z opisu. Szukając np. miedziorytów (wpisując skrót Kupfer.) odnajdujemy 1229 pozycji, w których poszukiwana fraza znajduje się w tytule dzieła, bądź w strefie opisu fizycznego.

Oczywiście zawsze pozostaje pewien niedosyt - co jeszcze można dodać do opisu, aby ułatwić badaczom dotarcie do poszukiwanego materiału. Przykładem może być postulat jaki odnośnie bazy VD 17 wysunął David Paisey ${ }^{48}$. Jego zdaniem niezmiernie potrzebne byłoby odnotowywanie sygnetów drukarskich. Choć wiele z nich widnieje na dołączanych kartach kluczowych (Schlüsselseiten), brak jednak o nich informacji w opisie bibliograficznym, a więc nie są one możliwe do wyszukiwania w bazie. Paisey ma nadzieję na stworzenie osobnej bazy internetowej poświęconej sygnetom (skoro takie informacje nie znalazły miejsca $\mathrm{w}$ bazie VD 17). Materiałem wyjściowym może być spis znaków drukarskich wynotowanych przez niego i przekazanych do HAB w Wolffenbüttel ${ }^{49}$.

Omawiając bazy VD 16, 17 i 18 należy wyrazić uznanie dla jakości sporządzanych opisów bibliograficznych, tym bardziej, że przygotowywane rekordy nie podlegaja dodatkowej korekcie. Nie znaczy to jednak, że są to opisy doskonałe (bezbłędne). Zdarzają się potknięcia czy nieścisłości. Jako przykład można podać dzieło z VD 17, którego kolejne edycje zostały przypisane dwóm autorom o podobnie brzmiącym nazwisku. Mowa o książce pt. Elenchus Plantarum z 1643 roku, autorstwa lekarza miejskiego z Gdańska Mikołaja Ölhafa ${ }^{50}$. Kolejne wydanie z 1656 roku, uznano błędnie za dzieło ewangelickiego teologa Nicolausa Hieronimusa Oelhafen von Schöllenbach ${ }^{51}$. W innym przypad-

${ }^{47}$ Spis skrótów do opisu materiału ilustracyjnego znajduje się na stronie informacyjnej o VD 16 (Abkürzungen zur Beschreibung von Buchsmuck und Beiwerk).

${ }^{48}$ D. Paisey, dz. cyt., s. 171.

${ }^{49}$ Można $\mathrm{w}$ tym miejscu nadmienić, że taką informację, tj. występowanie sygnetu drukarskiego odnotowuje się od niedawna w opisach bibliograficznych starych druków w NUKAT.

${ }^{50}$ VD17 1:061507M.

${ }^{51}$ VD17 14:073686Y. 
ku, jak podaje Wolfgang Müller ${ }^{52}$, dzieło zatytułowane Anna Elisabeth Most, Disputatio inauguralis, Von der Jungfrau-Liebe, welche mit Einwilligung der hochloblichen Weiber-Fakucultat unter dem Schutz der wohl-edlen, [...] Frauen Fr. Christiana Amalia von Blumenau [...], die hochste Ehre des Braut-Bettes zu erlangen, offentlich hielte... przy opisach kolejnych wydań otrzymało różne formy literacko-wydawnicze. Rekordy dla dziewięciu wydań tego dziełka, jakie znajdują się w bazie, sporządzili bibliotekarze sześciu różnych książnic. We wszystkich opisach odnajdujemy określenie „literatura kobieca” (Frauenliteratur), w siedmiu dodatkowo - ,satyra” (Satire), w dwóch - ,dysertacja” (Dissertation), a w jednym przypadku - ,pismo okolicznościowe: wesele” (Gelegenheistsschrift: Hochzeit). W ten sposób jedno dzieło otrzymało kilka form literacko-wydawniczych, co oczywiście nie jest błędem lecz pewną niekonsekwencją w sporządzaniu opisów.

Postulatem pozostaje również uzupełnianie baz. $\mathrm{Na}$ ich znaczące wzbogacenie miałoby wpływ włączenie w całe przedsięwzięcie większej ilości bibliotek, nie tylko naukowych książnic ze wszystkich landów niemieckich ale również innych typów librarii, np. miejskich, kościelnych czy szlacheckich, jak i mniejszych instytucji posiadajacych zbiory specjalne oraz archiwa ${ }^{53}$. Twórcy omawianych baz oczekuja, że kolejne biblioteki będą przystępować do współtworzenia katalogów. Na stronie głównej portalu VD 17 czytamy, iż opisy dotychczas nienotowanych w bazie egzemplarzy, należy przesyłać do jednej z trzech odpowiedzialnych za inicjatywę bibliotek, które mają za zadanie wprowadzić nowych współkatalogujących $\mathrm{w}$ tajniki reguł obowiązujących w VD. ${ }^{54}$ Oferują też pomoc mniejszym bibliotekom $\mathrm{m}$. in. przy tematowaniu, czy tworzeniu KHW. Informacja o książnicach dołączających do współkatalogowania, umieszczana jest regularnie na stronie internetowej projektu ${ }^{55}$.

Należy mieć zatem nadzieję, że z czasem bazy VD 16, VD 17 i VD 18, dzięki narastającej kooperacji bibliotecznej, obejmować będą jeśli nie całość, to większość piśmiennictwa niemieckiego, które wyszło spod pras drukarskich w epoce nowożytnej. Dzięki takim bazom wzrasta nasza wiedza na temat produkcji wydawniczej, działalności drukarzy, danych biograficznych i genealogicznych zarówno sprawców druków, jak i osób,

${ }^{52}$ W. Müller, dz. cyt., s. 53-54.

${ }^{53}$ W. Müller, dz. cyt., s. 55.

${ }^{54} \mathrm{Na}$ temat wymogów, zob. C. Fabian, T. Stäcker, A. Wehmeyer, Fortführung des VD 17. Perspektiven und Angebote der Trägerbibliotheken, [w:] Bibliothek und Wissenschaft..., s. 193-197 - tam m. in. najczęściej zadawane pytania dotyczące VD 17.

${ }_{55}$ Wykaz ponad 30 bibliotek współtworzących bazę znajduje się pod adresem http:// www.vd17.de/partners.html. (aktualnie strona w przebudowie - X 2013). 
którym zostały poświęcone (np. informują o datach śmierci czy koligacjach rodzinnych) oraz wielu innych aspektów związanych z książką zabytkowa ${ }^{56}$. A co najważniejsze, umożliwiają one szybkie odnalezienie opisów bądź pełnych tekstów starych druków w internecie oraz oferują różne możliwości wyszukiwawcze specjalistom reprezentującym wiele dyscyplin naukowych.

\section{Streszczenie}

\section{Retrospektywna bibliografia narodowa Niemiec online (VD 16, VD 17, VD 18). Prezentacja baz}

Na retrospektywną bibliografie narodową Niemiec składają się trzy katalogi rejestrujące piśmiennictwo z obszaru niemieckojęzycznego - Niemiec, Austrii, części Szwajcarii i Alzacji (niezależnie od języka tekstu) z okresu 1501-1800 (Das Verzeichnis der im deutschen Sprachbereich erschienenen Drucke des 16, 17, 18 Jahrhunderts). Omawiane katalogi (znane pod akronimem VD 16, 17, 18), powstały (i nadal są tworzone) dzięki kooperacji bibliotek (głównie) niemieckich na przestrzeni ostatnich 40 lat, przy subwencji Niemieckiego Towarzystwa na Rzecz Wspierania Nauki (DFG). Najstarszy z nich - VD 16 powstał w wersji papierowej, został przeniesiony do sieci i jest nadal uzupełniany (nowe rekordy nienotowanych dotąd edycji otrzymują symbol literowy ZV). Również VD 17 jest udoskonalana i uzupełniana o wersje cyfrowe opisywanych druków. Oprócz tradycyjnych danych bibliograficznych odnaleźć w niej czasem można specyfikację egzemplarzy. Natomiast prace nad tworzeniem bazy VD 18 znajdują się w fazie testowania.

Wszystkie trzy spisy są dostępne nieodpłatnie $\mathrm{w}$ internecie, umożliwiają szybkie dotarcie do opisów bądź pełnych tekstów starych druków oraz oferują różne możliwości wyszukiwawcze specjalistom reprezentującym wiele dyscyplin naukowych.

\section{Summary}

\section{German Retrospective National Bibliography Online Projects (VD 16, VD 17, VD 18): Presentation of the Databases}

The retrospective German National Bibliography - Das Verzeichnis der im deutschen Sprachbereich erschienenen Drucke des 16, 17, 18 Jahrhunderts -

${ }^{56}$ Ch. Reske, Das VD 17 als Quelle für die Buchwissenschaft, [w:] Bibliothek und Wissenschaft..., s. 135n. 
consists of three catalogues, which register printed matter from the German speaking territories, i.e. contemporary Germany, Austria, part of Switzerland and Alsace (notwithstanding the language publication language), dating from the period 1501-1800. The project started c. 40 years ago, thanks to the cooperation of a number of libraries, the majority of them German, and is supported by the German Research Foundation (Deutsche Forschungsgemeinschaft). The catalogues in question are popularly referred to as VD 16, VD 17, and VD 18. Initially, the first of these, VD 16, was a card catalogue, but with time it was converted into an internet database (records introduced afterwards are distinguish by the symbol "ZV"). The VD 17 is an enhanced database, supplemented by the addition of digitised versions of the described prints, while the VD 18 is still in the testing phase.

All three discussed databases are available on the internet, in open access. They offer immediate access to full bibliographic descriptions, or to the digitised versions. Apart from that, they provide the user with various searching techniques, enabling investigation in numerous fields of knowledge. 